\title{
Peranan Pemerintah Daerah di Era Reformasi
}

\begin{abstract}
Mhd.Ansori ${ }^{1}$
Abstrak
Negara Republik Indonesia sebagai negara kesatuan menganut asas desentralisasi dalam penyelenggaraan pemerintahan, dengan memberi kesempatan dan keleluasaan kepada Daerah untuk menyelenggarakan otonomi daerah. Dengan demikian, Otonomi Daerah adalah merupakan kebijaksanaan yang sangat sesuai dengan asas desentalisasi dalam kerangka Negara Kesatuan Republik Indonesia. Otonomi nyata adalah keleluasaan daerah untuk menyelenggarakan kewenangan pemerintahan di bidang tertentu yang secara nyata ada dan diperlukan serta tumbuh, hidup, dan berkembang di daerah. Tentunya hal ini untuk mewujudkan kemandirian, otonomi berkait erat dengan pola hubungan antara pusat dan daerah yang meliputi berbagai segi yaitu hubungan kewenangan, hubungan pengawasan, hubungan keuangan, dan lain sebagainya. Soewargono dan Djohan menyatakan bahwa salah satu fungsi utama dari pemerintah yaitu membuat kebijakan publik. Peran pemerintah lebih sebagai pelayan masyarakat yang tidak bertujuan memperoleh keuntungan dan bukan memenuhi apa yang menjadi kemauan birokrasi itu sendiri. Tujuan tulisan ini untuk mengetahui peranan pemerintah daerah di era reformasi kini. Tipe penelitian yang digunakan adalah penelitian yuridis normatif, menggunakan pendekatan konseptual, pendekatan perundangundangan, dan pendekatan sejarah.
\end{abstract}

\section{Kata Kunci : Otonomi, Penyelenggara Pemerintah, Pemerintah Daerah.}

\begin{abstract}
The republic of Indonesia as a unitary state embraces the principle of decentralization in the administration of goverment, by providing opportunies and freedom to the region to organize regional autonomy. Thus, regional autonomy is a policy that is in accordance with the principle of decentralization within the framework of the unitary state of the Indonesian republic. The real autonomy is the flexibility of the region to exercise the authority of the goverment in certain areas that are real and necessary and growing, living and developing in the regions. Of course this is to realize independence, autonomy is closely related to the pattern of relation between the central and regional which includes various aspects of the relationship of authority, supervisory relations, financial relations, and so forth traditional. Soewargono and Djohan stated that one of the main functions of goverment is to make public policy. The role of goverment is more as a servant of society that does not aim to gain profit rather than fulfill what the bureaucracy's own will. The purpose of this paper to know the role of local goverment in the current era of reformasi. The type of research used is normative juridical research, using conceptual approach, legislation approach, and historical approach.
\end{abstract}

Keyword : Autonomy, Goverment Administration, Local Goverment

${ }^{1}$ Mhd.Ansori, Dosen Fakultas Hukum Universitas Batanghari. 


\section{PENDAHULUAN}

Negara Republik Indonesia sebagai negara kesatuan menganut asas desentralisasi dalam penyelenggaraan pemerintahan, dengan memberi kesempatan dan keleluasaan kepada Daerah untuk menyelenggarakan otonomi daerah. ${ }^{2}$ Prinsip pada negara kesatuan ialah bahwa yang memegang tampuk kekuasaan tertinggi atas segenap urusan negara ialah pemerintah pusat tanpa adanya suatu delegasi atau pelimpahan kekuasaan kepada pemerintah daerah, dalam negara kesatuan terdapat asas bahwa segenap urusan-urusan negara tidak dibagi antara pemerintah pusat dan pemerintah lokal sehingga urusan-urusan negara dalam negara kesatuantetap merupakan suatu kebulatan dan pemegang kekuasaan tertinggi di negara itu ialah pemerintah pusat. ${ }^{3}$ Setelah diamandemen, Pasal 18 ayat (1) UUD 1945 menyatakan : "Negara Kesatuan Republik Indonesia dibagi atas daerah-daerah propinsi dan daerah propinsi itu dibagi atas kabupaten dan kota, yang tiap-tiap propinsi, kabupaten dan kota itu mempunyai pemerintahan daerah yang diatur dengan undang-undang”.

Otonomi daerah atau pemerintahan daerah seharusnya mendapat perhatian yang tidak kalah penting dalam pembaharuan UUD 1945, sejarah ketatanegaraan RI sudah sejak semula meletakkan otonomi daerah sebgai salah satu sendi penting penyelenggaraan pemerintahan negara, otonomi daerah diadakan bukan sekedar menjamin efisiensi penyelenggaraan pemerintahan, bukan pula sekedar menampung kenyataan negara yang luas, penduduk banyak, dan berpulau-pulau. ${ }^{4}$

Dengan demikian, "Otonomi Daerah adalah merupakan kebijaksanaan yang sangat sesuai dengan asas desentalisasi dalam kerangka Negara Kesatuan Republik Indonesia' 5

Sebagaimana termuat dalam Undang-Undang Nomor 23 Tahun 2014 Tentang Pemerintahan Daerah bahwa Pemerintahan Daerah adalah penyelenggaraan urusan pemerintahan oleh Pemerintah Daerah dan Dewan Perwakilan Rakyat Daerah menurut asas otonomi dan tugas pembantuan dengan prinsip otonomi seluas-luasnya dalam sistem dan prinsip Negara Kesatuan Republik Indonesia sebagaimana dimaksud dalam Undang-Undang Dasar Negara Republik Indonesia Tahun 1945, dan menyatakan bahwa Dewan Perwakilan Rakyat Daerah adalah lembaga perwakilan rakyat daerah yang berkedudukan sebagai unsur penyelenggara Pemerintahan Daerah.

Baik secara konseptual maupun hukum, pasal-pasal baru Pemerintahan Daerah dalam UUD 1945 memuat berbagai paradigma baru dan arah politik Pemerintahan Daerah yang baru pula, yang tampak dari prinsip dan ketentuan berikut :

1. Prinsip daerah mengatur dan mengurus sendiri urusan pemerintahan menurut asas otonomi dan tugas pembantuan;

2. Prinsip menjalankan otonomi seluas-luasnya;

3. Prinsip kekhususan dan keragaman daerah;

${ }^{2}$ Deddy Supriady Bratakusumah, Dadang Solihin, Otonomi Penyelenggaraan Pemerintahan Daerah, (Jakarta:Gramedia Pustaka Utama, 2002), hlm 1.

${ }^{3}$ Ni'matul Huda, Hukum Tata Negara Indonesia, (Yogyakarta:Raja Grafindo Persada, 2005), hlm. 92.

${ }^{4}$ Bagir Manan, Menyongsong Fajar Otonomi Daerah, (Yogyakarta:PSH FH UII,2004), hlm. 3.

${ }^{5}$ Syaukani HR, “Menatap Harapan Masa Depan Otonomi Daerah" Gerakan Pengembangan Peberdayaan Kutai, Lembaga Ilmu Pengetahuan, Kalimantan Timur, (2001): 193. 
4. Prinsip mengakui dan menghormati kesatuan masyarakat hukum adat beserta hak-hak tradisionalnya;

5. Prinsip mengakui dan menghormati Pemerintahan Daerah yang bersifat khusus dan istimewa;

6. Prinsip badan perwakilan dipilih langsung dalam suatu pemilihan umum;

7. Prinsip hubungan pusat dan daerah harus dilaksanakan secara selaras dan adil. ${ }^{6}$

Pemberian kedudukan Propinsi sebagai daerah otonom dan sekaligus sebagai wilayah administrasi dilakukan dengan pertimbangan :

1. untuk memelihara hubungan yang serasi antara pusat dan daerah dalam kerangka Negara Kesatuan Republik Indonesia.

2. Untuk menyelenggarakan otonomi daerah yang bersifat lintas daerah kabupaten dan daerah kota serta melaksanakan kewenangan otonomi daerah yang belum dapat dilaksanakan oleh daerah kabupaten dan daerah kota.

3. Untuk melaksankan tugas-tugas pemerintahan tertentu yang dilimpahkan dalam rangka pelaksanaan asas dekonsentrasi. ${ }^{7}$

Banyaknya anggaran belanja daerah yang tidak jelas serta melimpahnya permintaan fasilitas kesejahteraan para eksekutif tingkat daerah merupakan bukti yang nyata, karena ternyata di daerah masih minim staf ahli di bidang keuangan dan manajemen yang diperlukan. ${ }^{8}$ Sikap mentalitas aparatur pemerintahan daerah merupakan salah satu kunci penting keberhasilan pelaksanaan otonomi daerah, karena merekalah ujung tombak dan eksekutor program tersebut. Ada gejala cukup menonjol pada hampir semua pemerintah daerah bahwa sikap dan mentalitas aparatur eksekutif masih menyisakan pengaruh pemerintah yang sentralistik, sehingga mereka lebih baik menunggu dan kurang berani mengambil inisiatif dan prakarsa untuk melaksanakan fungsi keotonomian daerahnya, kondisi ini sudah tentu tidak menguntungkan pelaksanaan otonomi daerah. ${ }^{9}$ Untuk mencegah politik otonomi daerah yang zig-zag yang cenderung merugikan kepentingan daerah, perlu ada dasar konsitusional yang lebih kuat dan rinci, dalam pembaharuan UUD 1945 sangat penting memperbaharui ketentuan mengenai pemerintahan daerah. ${ }^{10}$

Tujuan tulisan ini untuk mengetahui peranan pemerintah daerah di era reformasi kini dan rencana pemecahan masalah dengan merumuskan suatu kajian yang terbatas pada "Bagaimana peranan pemerintah daerah di era reformasi ?"

\section{Tinjauan Pustaka}

Reformasi Mei 1998 telah membawa berbagai perubahan mendasar dalam kehidupan bernegara dan berbangsa Indonesia ;

1. sejak jatuhnya Soeharto, kita tidak lagi memiliki seorang pemimpin sentral dan menentukan. Munculnya pusat-pusat kekuasaan baru di luar negara telah menggeser kedudukan seorang Presiden RI dari penguasa hegemonik dan monopolistik menjadi kepala pemerintahan biasa, yang sewaktu-waktu dapat digugat bahkan diturunkan dari kekuasaannya.

${ }^{6}$ Ni'matul Huda, Otonomi Daerah Filosofi, Sejarah Perkembangan, dan Problematika, (Yogyakarta: Pustaka Pelajar, 2005), hlm. 23.

${ }^{7}$ Deddy Supriady Bratakusumah, Dadang Solihin, Op.Cit. hlm. 3

${ }^{8}$ Hasan Mustafa, Op.cit. hlm. 6

${ }^{9}$ Hasan Mustafa, "SDM dan Otonomi Daerah", Palu, (2002): 5

${ }^{10}$ Bagir Manan, Op.Cit. hlm. 5. 
2. Munculnya kehidupan politik yang lebih liberal, yang melahirkan proses politik yang juga liberal.

3. Reformasi politik juga telah mempercepat pencerahan politik rakyat. Semangat keterbukaan yang dibawanya telah memperlihatkan kepada publik betapa tingginya tingkat distorsi dari proses penyelenggaraan negara.

4. Pada tataran lembaga tinggi negara, kesadaran untuk memperkuat proses check and balances antara cabang-cabang kekuasaan telah berkembang sedemikian rupa bahkan melampaui konvensi yang selama ini dipegang yakni"asas kekeluarggaan" di dalam penyelenggaraan negara.

5. Reformasi politik telah mempertebal keinginan sebagian elite berpengaruh dan publik politik Indonesia untuk secara sistematik dan damai melakukan perubahan mendasar dalam konstitusi RI. ${ }^{11}$

Melihat pertumbuhannya, demokrasi terus berkembang, sehingga tepat apa yang dikemukakan Bagir Manan, bahwa demokrasi merupakan suatu fenomena yang tumbuh, bukan suatu penciptaan, sebuah negara dapat dikatakan demokrasi paling tidak memenuhi unsur-unsur yaitu :

1. Ada kebebasan untuk membentuk dan menjadi anggota perkumpulan.

2. Ada kebebasan menyatakan pendapat.

3. Ada hak untuk memberikan suara dalam pemungutan suara.

4. Ada kesempatan untuk dipilih atau menduduki berbagai jabatan pemerintah atau negara.

5. Ada hak bagi para aktivis politik berkampanye untuk memperoleh dukungan atau suara.

6. Terdapat berbagai sumber informasi.

7. Ada pemilihan yang bebas dan jujur.

8. Semua lembaga yang bertugas merumuskan kebijakan pemerintah, harus bergantung kepada keinginan rakyat. ${ }^{12}$

Pemerintah diartikan sebagai sekelompok orang yang bertanggung jawab atas penggunaan kekuasaan, Max Webber menyimpulkan bahwa pemerintah tidak lain merupakan apa pun yang berhasil menopang klaim bahwa dialah yang secara eksklusif berhak menggunakan kekuatan fisik untuk memaksakan aturanaturannya dalam suatu wilayah tertentu. ${ }^{13}$

Teori pembagian kekuasaan merupakan salah satu dasar untuk mengkaji tentang pola hubungan kewenangan antara DPRD dengan Kepala Daerah, karena hubungan tersebut merupakan salah satu deskripsi adanya pembagian kekuasaan dalam negara, baik antara Pemerintah Pusat dengan Pemerintah Daerah maupun antara organ-organ pemerintahan yang ada di daerah. ${ }^{14}$

Berdasarkan ketentuan Undang-Undang Nomor 32 Tahun 2004 Tentang Pemerintahan Daerah Pasal 19 ayat (2) menyatakan bahwa "Penyelenggara pemerintahan daerah adalah pemerintah daerah dan Dewan Perwakilan Rakyat Daerah". Penyelenggaraan "fungsi pemerintahan daerah akan terlaksana optimal

\footnotetext{
${ }^{11} \mathrm{Ni}$ 'matul Huda, Hukum Tata Negara Indonesia, Op.Cit. hlm. 99.

${ }^{12}$ Juanda, Op.Cit. hlm. 19.

${ }^{13}$ Muhadam Labolo, Memahami Ilmu Pemerintahan, (Jakarta:Raja Grafindo Persada,2008), hlm. 16

${ }^{14}$ Juanda,Op.Cit. hlm. 17.
} 
bila penyelenggaraannya diikuti dengan sumber penerimaan yang cukup kepada daerah" $"$.

Perlu digarisbawahi bahwa otonomi bukan dan tidak bisa dijadikan sebagai instrumen untuk menjustifikasi penyangkalan terhadap keindonesiaan dan sekaligus sebagai pembenaran atas kebangkitan dan pemujaan terhadap politik kesukuan, otonomi daerah merupakan jawaban terhadap persoalan kedaerahan Indonesia, disamping bagi demokrasi, keadilan dan juga efektivitas penyelenggaraan pemerintahan dan pelayanan publik. ${ }^{16}$

Otonomi nyata adalah keleluasaan daerah untuk menyelenggarakan kewenangan pemerintahan di bidang tertentu yang secara nyata ada dan diperlukan serta tumbuh, hidup, dan berkembang di daerah. ${ }^{17}$ Namun ada beberapa persoalan lama yang belum tuntas dan persoalan baru :

1. berkait dengan hubungan kekuasaan pemerintah pusat dan pemerintah daerah, sering dipertanyakan dimanakah locus kekuasaan seharusnya berada.

2. Kompleksitas persoalan otonomi daerah di Indonesia juga terkait dengan hubungan keuangan pusat dan daerah. Banyak orang percaya bahwa dia atas segalaragam perdebatan lainnya, maka persoalan inilah yang sebenarnya paling menentukan dalam hubungan pusat dan daerah di Indonesia.

3. Otonomi daerah di Indonesia juga berhadapan dengan persolan "desentralisasi semu" akibat logika-logika kepartaian yang masih sangat sentralistis.

4. Sebagian masih berkait dengan poin ketiga di atas, terdapat juga persolan berkaitan dengan penataan politik lokal.

5. Terdapat pula kompleksitas persoalan dalam otonomi daerah berkaitan dengan menguatnya 'daerahisme'.

6. Otonomi daerah memerlukan perhatian khusus denga upaya mereformat hubungan antarv 'level' pemerintahan di tingkat lokal.

7. Terdapat problematika hubungan antar daerah.

8. Problematika hubungan eksekutif dan legislatif di daerah.

9. Terdapat masalah hubungan antara negara dan masyarakat di tingkat lokal.

10. Permasalahan dalam implementasi otonomi dalam kaitannya dengan penataan institusi dan mekanisme lokal. ${ }^{18}$

Soewargono dan Djohan menyatakan bahwa salah satu fungsi utama dari pemerintah yaitu membuat kebijakan publik. ${ }^{19}$ Bruggink menyatakan, "bahwa aturan hukum yang dirumuskan dalam sebuah peraturan perundang-undangan, menjadikan orang dengan kepastian dapat mengatakan bahwa ia ditetapkan oleh pengemban kewenangan hukum" ${ }^{20}$ dari pendapat Bruggink dapat disimpulkan "bahwa peraturan perundang-undangan adalah bagian dari aturan hukum dalam bentuk hukum tertulis, merupakan hukum positif". ${ }^{21}$

\section{METODE PENELITIAN}

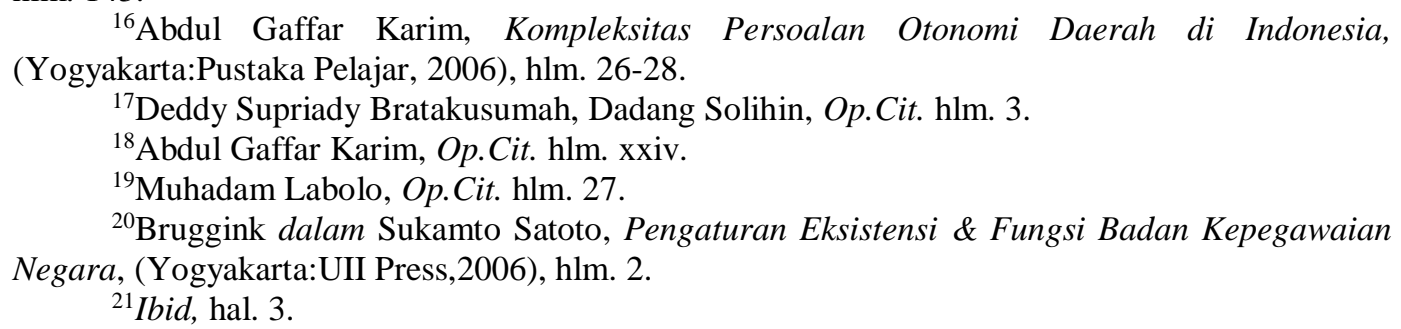

${ }^{16}$ Abdul Gaffar Karim, Kompleksitas Persoalan Otonomi Daerah di Indonesia, (Yogyakarta:Pustaka Pelajar, 2006), hlm. 26-28.

${ }^{17}$ Deddy Supriady Bratakusumah, Dadang Solihin, Op.Cit. hlm. 3.

${ }^{18}$ Abdul Gaffar Karim, Op.Cit. hlm. xxiv.

${ }^{19}$ Muhadam Labolo, Op.Cit. hlm. 27.

${ }^{20}$ Bruggink dalam Sukamto Satoto, Pengaturan Eksistensi \& Fungsi Badan Kepegawaian Negara, (Yogyakarta:UII Press,2006), hlm. 2.

${ }^{21}$ Ibid, hal. 3 . hlm. 143

${ }^{15}$ HAW.Widjaja, Penyelenggaraan Otonomi di Indonesia, (Jakarta:Rajawali Pers, 2005), 
Tipe penelitian yang digunakan adalah penelitian yuridis normatif, Penelitian ini menggunakan "pendekatan konseptual, pendekatan perundangundangan, dan pendekatan sejarah"22.

Bahan-bahan hukum yang telah diperoleh, diinventarisasi dan diidentifikasi untuk digunakan sebagai bahan dalam menganalisis pokok permasalahan dalam penelitian ini. Identifikasi bahan hukum baik primer, sekunder, maupun tertier dilakukan secara kritis, logis, dan sistematis, dikumpulkan berdasarkan sistem kartu (card system), "yang memuat sumber yang tepat dari mana catatan itu diambil, informasi atau pendapat yang digunakan, pokok masalah serta kartu yang digunakan adalah kartu kutipan, kartu ulasan, kartu ikhtisar" 23 hal ini dilakukan untuk mempermudah proses pengolahan data hukum tersebut, dengan demikian bahan hukum akan disusun dan digolongkan menurut bentuk, jenis dan tingkatnya. Adapun bahan hukum yang digunakan dalam penelitian ini adalah:

a. Bahan hukum primer terdiri dari peraturan perundang-undangan yang berhubungan dengan masalah yang dibahas seperti: UUD 1945, UndangUndang, Peraturan Pemerintah, Peraturan Daerah, dan lain-lain.

b. Bahan hukum sekunder yaitu bahan hukum yang dapat memberikan penjelasan mengenai bahan hukum primer, seperti: rancangan undang-undang, hasil-hasil penelitian, hasil karya dari kalangan hukum baik berbentuk buku, jurnal hukum, makalah dan lain-lain.

c. Bahan hukum tertier yakni bahan hukum yang dapat memberikan petunjuk maupun penjelasan terhadap bahan hukum primer dan sekunder. Contohnya: kamus, ensiklopedia, indeks komulatif,dan lain-lain

Kemudian dianalisa dengan cara :

1) Menginterpretasikan semua peraturan perundang-undangan sesuai masalah yang dibahas.

2) Menilai bahan-bahan hukum yang berhubungan dengan masalah yang diteliti.

3) Mengevaluasi peraturan perundang-undangan yang berhubungan dengan masalah yang dibahas.

\section{HASIL DAN PEMBAHASAN}

Pembagian kekuasaan secara vertikal lazim dikenal sebagai pembagian kekuasaan secara teritorial menunjuk pada pembagian kekuasaan antara beberapa tingkat pemerintahan, sementara itu pembagian kekuasaan secara horizontal menunjuk pada pembagian fungsi-fungsi antara organ-organ kenegaraan, sebagai organ yang diberikan tanggung jawab dalam penyelenggaraan pemerintahan daerah (Kepala Daerah dan DPRD) memiliki fungsi dan kewenangan masingmasing di samping pada saat tertentu ada hubungannya satu sama lain. ${ }^{24}$ Oleh karena itu, "hukum merupakan instrumen utama dalam penyelenggaraan pemerintahan Indonesia". 25

Dalam pandangan lain, pemerintah adalah "segenap alat perlengkapan negara atau lembaga-lembaga kenegaraan yang berfungsi sebagai alat untuk mencapai tujuan negara" untuk itu pemerintah memiliki dua fungsi yaitu fungsi hlm. 92 .

${ }^{22}$ Bahder Johan Nasution, Metode Penelitian Ilmu Hukum, (Bandung:Mandar Maju,2008),

${ }^{23}$ Ibid., hal. 106.

${ }^{24}$ Juanda, Op.Cit. hlm. 3.

${ }^{25}$ H.Abdul Latief, Op.Cit. hlm. 21. 
primer ialah fungsi pemerintah sebagai provider jasa-jasa publik yang tidak dapat diprivatisasikan dan fungsi sekunder ialah fungsi pemerintah sebagai provider kebutuhan dan tuntutan yang diperintah akan barang dan jasa. ${ }^{26}$

Fungsi dan kewenangan Pemerintah Daerah termuat dalam UUD 1945 Pasal 18, Pasal 18A, Pasal 18B dimaksudkan untuk memperjelas pembagian daerah dalam NKRI yang meliputi daerah provinsi dan dalam daerah provinsi terdapat daerah kabupaten dan kota.

Otonomi bukan sekedar pemencaran penyelenggaraan pemerintahan untuk mencapai efisiensi dan efektivitas pemerintahan, otonomi adalah sebuah tatanan ketatanegaraan, bukan hanya tatanan administrasi negara. ${ }^{27}$

Perubahan posisi antara Kepala Daerah dan DPRD tidak lepas dari perbedaan corak atau langgamperaturan perundang-undangan yang mengatur tentang Pemerintahan Daerah, kalau UU No.5 Tahun 1974 bercorak sentralistik, UU No.22 Tahun 1999 lebih menampakkan semangat desentralistiknya, meskipun masih ada beberapa hal yang tidak bisa dihilangkan begitu saja corak sentralistiknya. ${ }^{28}$ Disahkannya UU No.22 Tahun 1999 dan UU No.25 Tahun 1999 memberikan harapan baru bagi pengembangan otonomi yang sebenarnya, pengembangan otonomi daerah saat ini diselenggarakan dengan memperhatikan prisip-prinsip demokrasi, peran serta masyarakat, pemerataan, dan keadilan, serta memperhatikan potensi dan keanekaragaman daerah. ${ }^{29}$

Di dalam UU No.32 tahun 2004 ditegaskan, bahwa Pemerintah Daerah dalam penyelenggaraan urusan pemerintahan memiliki hubungan dengan pemerintah dan Pemerintah Daerah lainnya, hubungan tersebut meliputi hubungan wewenang, keuangan, pelayanan umum, pemanfaatan sumber daya alam dan sumber daya lainnya menimbulkan hubungan administrasi dan kewilayahan antarsusunan pemerintahan. ${ }^{30}$

Selama ini dipahami bahwa penyelenggaraan pemerintahan di daerah didasarkan tiga asas, yaitu :

1. asas desentralisasi definisinya menurut Joeniarto desentralisasi adalah memberikan wewenang dari pemerintah negara kepada pemerintah lokal untuk mengatur dan mengurus urusan tertentu sebagai urusan rumah tangganya sendiri dan menurut Amrah Muslimin, mengartikan desentralisasi adalah pelimpahan wewenang pada badan-badan dan golongan-golongan dalam masyarakat dalam daerah tertentu untuk mengurus rumah tangganya sendiri.

2. Asas dekonsentrasi ialah pelimpahan sebagian dari kewenangan pemerintah pusat pada alat-alat pemerintah pusat yang ada di daerah menurut Amrah Muslimin dan menurut Joeniarto dekonsentrasi adalah pemberian wewenang oleh pemerintah pusat kepada alat-alat perlengkapan bawahan untuk menyelenggarakan urusan-urusannya yang terdapat di daerah. Asas dekonsentrasi dapat ditinjau dari tiga segi, yaitu dari segi wewenang, dari segi pembentuk pemerintah, dari segi pembagian wilayah.

\footnotetext{
${ }^{26}$ Muhadam Labolo, Op.Cit. hlm. 26.

${ }^{27}$ Bagir Manan, Op.Cit. hlm. 25.

${ }^{28}$ Ni'matul Huda, Otonomi Daerah Filosofi, Sejarah Perkembangan, dan Problematika, Op.Cit. hlm. 189.

${ }^{29}$ Mardiasmo, Otonomi dan Manajemen Keuangan Daerah,(Yogyakarta:ANDI,2004), hlm. 12.

${ }^{30}$ Ni'matul Huda, Otonomi Daerah Filosofi, Sejarah Perkembangan, dan Problematika, Op.Cit. hlm. 95.
} 
3. Asas tugas pembantuan, menurut Joeniarto tugas pembantuan ialah tugas ikut melaksanakan urusan-urusan pemerintah pusat atau pemerintah lokal yang berhak mengatur dan mengurus rumah tangga tingkat atasannya. ${ }^{31}$

Pemberian otonomi daerah akan mengubah perilaku pemerintah daerah untuk lebih efisien dan profesional, untuk meningkatkannya pemerintah daerah perlu melakukan perekayasaan ulang terhadap birokrasi yang selama ini dijalankan. ${ }^{32}$

Tema sentral reformasi total adalah mewujudkan masyarakat madani, terciptanya good governance, dan mengembangkan model pembangunan yang berkeadilan. ${ }^{33}$ Prinsip penyelenggaraan pemerintahan daerah yaitu :

a. Digunakannya asas desentralisasi, dekonsentrasi, dan tugas pembantuan.

b. Penyelenggaraan asas desentralisasi secara utuh dan bulat yang dilaksanakan di Daerah Kabupaten dan Daerah Kota.

c. Asas tugas pembantuan yang dapat dilaksanakan di Daerah Propinsi, Daerah Kabupaten, Daerah Kota dan Desa. ${ }^{34}$

Penyelenggaraan Pilkada yang berlangsung selama ini telah pula melahirkan power seeking society, gejala ini menunjukkan munculnya suatu bargaining position antar berbagai stakeholders, selain itu meningkatnya politik lokal. ${ }^{35}$

Untuk menjadi Kepala Daerah, seseorang diharuskan memenuhi persyaratan tertentu yang intinya agar Kepala Daerah selalu bertakwa kepada Tuhan Yang Maha Esa, memiliki etika dan moral, berpengetahuan, dan berkemampuan sebagai pimpinan pemerintahan, berwawasan kebangsaan, serta mendapatkan kepercayaan rakyat. ${ }^{36}$

Rasyid membagi fungsi pemerintahan menjadi empat bagian, yaitu pelayanan, pembangunan, pemberdayaan, dan pengaturan bila dijalankan pada saat tertentu akan menggambarkan kualitas pemerintahan itu sendiri, jika pemerintah dapat menjalankan fungsi fungsinya dengan baik, tugas pokok selanjutnya adalah bagaimana pelayanan dapat membuahkan keadilan, pemberdayaan yang membuahkan kemandirian, serta pembangunan yang menciptakan kemakmuran. ${ }^{37}$

Kewenangan daerah mencakup kewenangan dalam seluruh bidang pemerintahan, kecuali kewenangan dalam bidang politik luar negeri, pertahanan keamanan, peradilan, moneter dan fiskal, agamadan kewenangan bidang lain. ${ }^{38}$

Dalam upaya pemberdayaan pemerintah daerah ini, maka perspektif perubahan yang diinginkan dalam pengelolaan keuangan daerah dan anggaran daerah sebagai berikut :

1. Pengelolaan keuangan daerah harus bertumpu pada kepentingan publik. Hal ini tidak saja terlihat pada besarnya porsi pengalokasian anggaran untuk

\footnotetext{
${ }^{31}$ Ibid. hlm. 312.

${ }^{32}$ Mardiasmo, Op.Cit. hlm. 11.

${ }^{33}$ Ibid. hlm. 3.

${ }^{34}$ Deddy Supriady Bratakusumah, Dadang Solihin, Op.Cit. hlm. 6.

${ }^{35}$ M.Zaki Mubarak dkk, Blue Print Otonomi Daerah Indonesia, (Jakarta:Yayasan Harkat

${ }^{36}$ Deddy Supriady Bratakusumah, Op.Cit. hlm. 7.

${ }^{37}$ Muhadam Labolo, Op.Cit. hlm. 23.

${ }^{38}$ Deddy Supriady Bratakusumah, Dadang Solihin, Op.Cit, hlm. 10
} Bangsa, 2006), hlm. 113. 
kepentingan publik, tetapi juga terlihat pada besarnya partisipasi masyarakat dalam perencanaan, pelaksanaan, dan pengawasan keuangan daerah.

2. Kejelasan tentang misi pengelolaan keuangan daerah pada umumnya dan anggaran daerah pada khususnya.

3. Desentralisasi pengelolaan keuangan dan kejelasan peran para partisipan yang terkait dalam pengelolaan anggaran, seperti DPRD, KDH, Sekda dan perangkat daerah lainnya.

4. Kerangka hukum dan administrasi bagi pembiayaan, investasi, dan pengelolaan uang daerah berdasarkan kaidah mekanisme pasar, value for money, transparansi dan akuntabilitas.

5. Kejelasan tentang kedudukan keuangan DPRD, KDH, dan PNS-Daerah, baik ratio maupun dasar pertimbangannya.

6. Ketentuan tentang bentuk dan struktur anggaran, anggaran kinerja, dan anggaran multi-tahunan.

7. Prinsip pengadaan dan pengelolaan barang daerah yang lebih profesional.

8. Prinsip akuntansi pemerintah daerah, laporan keuangan, peran DPRD, dan akuntan publik dalam pengawasan, pemberian opini dan rating kinerja anggaran, dan transparansi informasi anggaran kepada publik.

9. Aspek pembinaan dan pengawasan yang meliputi batasan pembinaan, peran asosiasi, dan peran anggota masyarakat guna pengembangan profesionalisme aparat pemerintah daerah.

10. Pengembangan sistem informasi keuangan daerah untuk menyediakan informasi anggaran yang akurat dan pengembangan komitmen pemerintah daerah terhadap penyebarluasan informasi sehingga memudahkan pelaporan dan pengendalian, serta mempermudahkan mendapatkan informasi. ${ }^{39}$

Tentunya hal ini untuk mewujudkan kemandirian, otonomi berkait erat dengan pola hubungan antara pusat dan daerah yang meliputi berbagai segi yaitu hubungan kewenangan, hubungan pengawasan, hubungan keuangan, dan lain sebagainya. ${ }^{40}$

Baik secara konseptual maupun hukum, pasal-pasal baru Pemerintahan Daerah dalam UUD memuat berbagai paradigma baru dan arah politik Pemerintahan Daerah yang baru pula, yang tampak dari prinsip dan ketentuan berikut :

1. Prinsip daerah mengatur dan mengurus sendiri urusan pemerintahan menurut asas otonomi dan tugas pembantuan (Pasal 18 ayat (2));

Ketentuan ini menegaskan bahwa pemerintahan daerah adalah suatu pemerintahan otonom dalam negara kesatuan Republik Indonesia. Dalam pemerintahan daerah hanya ada pemerintahan otonomi, akibatnya muncul penjelasan yang berbunyi "daerah-daerah itu bersifat otonom atau bersifat daerah administrasi belaka". Tidak ada lagi unsur pemerintahan sentralisasi dalam pemerintahan daerah.

2. Prinsip menjalankan otonomi seluas-luasnya (Pasal 18 ayat (5));

Kehendak melaksanakan otonomi seluas-luasnya telah ada pada saat BPUPKI menyusun rancangan UUD, kehendak ini kemudian ditegaskan dalam UUDS 1950 pasal 131 ayat (2). Pasal 18 yang baru menegaskan pelaksanaan otonomi seluas-luasnya, selain dalam pengertianurusan atau funsi pemerintahan,

\footnotetext{
${ }^{39}$ Mardiasmo, Op.Cit. hlm. 10

${ }^{40}$ Bagir Manan, Op.Cit. hlm. 26
} 
otonomi luas harus tercermin pada kemandirian dan kebebasan daerah, campur tangan pusat harus dibatasi.

3. Prinsip kekhususan dan keragaman daerah (Pasal 18A, ayat (1));

Prinsip ini mengandung makna bahwa bentuk dan isi otonomi daerah tidak harus seragam. Bentuk dan isi otonomi daerah ditentukan oleh berbagai keadaan khusus dan keragaman setiap daerah. Inilah aspek penting paham otonomi nyata, yaitu otonomi beragam.

4. Prinsip mengakui dan menghormati kesatuan masyarakat hukum adat beserta hak-hak tradisionalnya(Pasal 18B, ayat (2));

Yang dimaksud masyarakat hukum adat adalah masyarakat hukum yang berdasarkan hukum adat atau adat istiadat seperti desa, marga, nagari, gampong, meunasah, huta, negorij dll. Kesatuan masyarakat hukum ini tidak hanya diakui tetapi dihormati, artinya mempunyai hak hidup yang sederajat dan sama pentingnya dengan kesatuan pemerintahan lain seperti kabupaten dan kota.

Selanjutnya, hak-hak tradisional yang ada diakui dan dijunjung tinggi. Hak tradisional ini meliputi hak ulayat, hak memperoleh manfaat dari tanah air, atau hasil hutan dan lain-lain disekitarnya. Dikatakan, bahwa pengakuan dan penghormatan itu diberikan sepanjang masyarakat hukum dan hak-hak tradisional masih nyata ada dan berfungsi, dan sesuai dengan prinsip negara kesatuan.

5. Prinsip mengakui dan menghormati Pemerintahan Daerah yang bersifat khusus dan istimewa(Pasal 18B ayat (1));

Undang-undanglah yang mengatur hal tersebut, setiap daerah dapat menuntut suatu kekhususan, semata-mata berdasarkan faktor-faktor tertentu, apalagi kekhususan itu mengandung muatan privilege tertentu yang tidak dimiliki daerah lain.

6. Prinsip badan perwakilan dipilih langsung dalam suatu pemilihan umum (Pasal 18 ayat (3));

Dengan demikian tidak ada lagi keanggotaan DPRD yang diangkat. Hal yang sama berlaku juga untuk keanggotaan DPR. Tidak demikian mengenai gubernur, bupati, walikota, hanya disebutkan : "dipilih secara demokratis".

7. Prinsip hubungan pusat dan daerah harus dilaksanakan secara selaras dan adil(Pasal 18 A ayat (2)).

Meskipun tidak ada satu ukuran tertentu mengenai hubungan yang adil dan selaras, prinsip ini menunjukkan, bahwa daerahberhak memperoleh secara wajar segala sumber daya untuk mewujudkan pemerintahan daerah yang mandiri dan kesejahteraan rakyat daerah yang bersangkutan. ${ }^{41}$

Peran pemerintah lebih sebagai pelayan masyarakat yang tidak bertujuan memperoleh keuntungan sehingga haruslah"meeting needs of the customer, not the bureaucracy", di mana lebih mementingkan terpenuhinya kepuasan pelanggan dan bukan memenuhi apa yang menjadi kemauan birokrasi itu sendiri. ${ }^{42}$

Penyelenggaraan pemerintahan yang baik, tidak semata-mata terjadi karena ketentuan hukum yang tidak jelas, manajemen pemerintahan yang kurang baik berbagai faktor tata laksana pemerintahan lainnya, tatana politik yang berlaku

\footnotetext{
${ }^{41}$ Ibid.

${ }^{42}$ Muhadam Labolo, Op.Cit.hlm. 29.
} 
dapat mempengaruhi bahkan menentukan penyelenggaraan pemerintahan, faktor lain yang memepengaruhi adalah ketidakpastian dalam penegakan hukum. ${ }^{43}$

Dalam praktik pemerintahan, kebanyakan rakyat lebih dulu memberikan apresiasi atas pelayanan pemerintahnya hingga berlebihan, tanpa menyadari bahwa upaya mendorong optimalisasi pelayanan yang diharapkan hanya akan terwujud apabila diimbangi pula dengan pelayanan yang maksimal dari rakyatnya, kadangkala pemerintah harus memberilebih banyak pelayanan kepada rakyatnya untuk menjaga keharmonisan, stabilitas, dan integrasi wilayahnya, pemberian pelayanan yang bersifat istimewa terhadap rakyat hanyalah dalam konteks merangsang kreativitas, kemandirian, penghargaan atas prestasi yang ditunjukkan sehingga terhindar dari perpecahan yang tidak diinginkan. ${ }^{44}$

Usaha mewujudkan pemerintahan yang baik, dilakukan terhadap ;

1. Melanjutkan pembaharuan politik, peraturan perundang-undangan di bidang politik yang menjadi dasar pembentukan pemerintahan baru, harus diperbaharui. Ketentuan mengenai sistem pemilu, susunan MPR,DPR,DPRD, KPU yang independen dan lain lain perlu ditata kembali.

2. Melanjutka pembaharuan UUD, pembaharuan ini tidak hanya mengenai jabatan kepresidenan, tetapi perbaikan menyeluruh termasuk menyusun kembali badan perwakilan menuju sistem dua kamar. Demikian pula mengenai lembaga negara lain, disamping ketentuan-ketentuan mengenai hak asasi, dan lain sebagainya.

3. Melanjutkan pembaharuan kekuasaan kehakiman seperti sistem pemilihan hakim agung, pertanggungjawaban hakim yang melanggar hukum, wewenang menguji tindakan pemerintahan dan peraturan perundang-undangan di bawah UUD, masa jabatan hakim dan lain sebagainya.

4. Pembaharuan administrasi negara, melanjutkan pembebasan administrasi negara dari segala pengaruh politik. Penyusunan kembali organisasi administrasi negara. Menyiapkan daerah untuk menjalankan tatanan otonomi baru yang meletakkan titik berat penyelenggaraan pemerintahan di daerah.

5. Ketegasan dalam menjalankan prinsip dan ketentuan hukum untuk menjamin kepastian, ketertiban, dan keadilan hukum

6. Melakukan evaluasi terhadap segala produk hukum di masa lalu, dalm rangka membangun satu tertib hukumyang utuh dan harmonis satu sama lain.

7. Menata pemerintahan desa agar mampu menjalankan pemerintahan yang bersentuhan langsung dengan rakyat banyak. ${ }^{45}$

\section{SIMPULAN}

Dengan diamandemennya UUD 1945 terkait Pemerintahan Daerah sebagaimana termuat pada Pasal 18, Pasal 18A, Pasal 18B kemudian berlakunya UU No.23 Tahun 2014 tentang Pemerintahan Daerah merubah posisi Pemerintah Daerah menjadi lebih baik sehingga lebih berperan dalam mensejahterakan rakyatnya, tentunya hal ini merupakan salah satu tujuan otonomi daerah.

\section{DAFTAR PUSTAKA \\ Buku}

\footnotetext{
${ }^{43}$ Bagir Manan, Op.Cit. hlm. 277.

${ }^{44}$ Muhadam Labolo, Op.Cit. hlm. 45.

${ }^{45}$ Bagir Manan, Op.Cit. hlm. 281
} 
Asshidiqie, Jimly, Pengantar Ilmu Jukum Tata Negara, Jakarata:Rajawali Pers, 2009.

Budiardjo, Miriam, Menggapai Kedaulatan untuk Rakyat, Bandung:Mizan Pustaka,1998.

Bratakusumah Deddy Supriady, Solihin Dadang, Otonomi Penyelenggaraan Pemerintahan Daerah, Jakarta:Gramedia Pustaka Utama, 2002.

Huda Ni'matul, Hukum Tata Negara Indonesia, Yogyakarta:Raja Grafindo Persada, 2005.

Huda, Ni'matul, Otonomi Daerah Filosofi, Sejarah Perkembangan, dan Problematika, Yogyakarta: Pustaka Pelajar, 2005.

Juanda, Hukum Pemerintahan Daerah, Bandung:Alumni,2004.

Karim Abdul Gaffar , Kompleksitas Persoalan Otonomi Daerah di Indonesia, Yogyakarta:Pustaka Pelajar, 2006.

Labolo, Muhadam, Memahami Ilmu Pemerintahan, Jakarta:Raja Grafindo Persada,2008.

Latief, H.Abdul, Hukum dan Peraturan Kebijaksanaan pada Pemerintahan Daerah. Yogyakarta:UII Press, 2005.

Manan Bagir, Menyongsong Fajar Otonomi Daerah, Yogyakarta:PSH FH UII,2004.

Mardiasmo, Otonomi dan Manajemen Keuangan Daerah,Yogyakarta:ANDI,2004.

Mubarak, M.Zaki dkk, Blue Print Otonomi Daerah Indonesia, Jakarta:Yayasan Harkat Bangsa, 2006.

Nasution Bahder Johan, Metode Penelitian Ilmu Hukum, Bandung:Mandar Maju,2008.

Widjaja, HAW, Penyelenggaraan Otonomi di Indonesia, Jakarta:Rajawali Pers, 2005.

Salam, Dharma Setyawan, Otonomi Daerah dalam Perspektif Lingkungan, Nilai, dan Sumber Daya, Jakarta: Djambatan,2007.

Satoto, Sukamto, Pengaturan Eksistensi \& Fungsi Badan Kepegawaian Negara, Yogyakarta:UII Press,2006.

\section{Jurnal}

Mustafa, Hasan, SDM dan Otonomi Daerah”, Palu, 2002.

Hartati, "Kebijakan Dibidang Perencanaan dan Penganggaran Daerah serta Permasalahan dalam Implementasinya", Bahan Kuliah, Program Pascasarjana Fakultas Hukum UNJA, 2009.

HR Syaukani, "Menatap Harapan Masa Depan Otonomi Daerah" Gerakan Pengembangan Pemberdayaan Kutai, Lembaga Ilmu Pengetahuan, Kalimantan Timur,2001. 